FACTA UNIVERSITATIS

Series: Economics and Organization Vol. 15, N ${ }^{\mathrm{o}} 3$, 2018, pp. 203 - 215

https://doi.org/10.22190/FUEO1803203M

Preliminary Communication

\title{
THE INFLUENCE OF PSYCHOLOGICAL CONTRACT BREACH ON JOB SATISFACTION
}

\author{
UDC 005.32:331.101.32
}

\author{
Sandra Milanović*, Milica Đokić*, Biljana Đorđević \\ University of Niš, Faculty of Economics, Serbia
}

\begin{abstract}
Psychological contract represents the implicit assumptions of the employees (or employer) regarding the content of their mutual exchange in addition to those that are specified in the formal employment contract. In the case of breaching it, many negatively consequences could arise. One of them is the lower level of job satisfaction. In the study that has been conducted we tried to find out the answer whether the psychological contract breach in unfavorable economic conditions negatively influences job satisfaction as it has been found in most studies conducted in developed countries. The research method that we used was the case study method. In order to test the hypothesis, we used ANOVA test and linear regression. The results of the study showed that psychological contract breach negatively influences job satisfaction of employees despite the unfavorable economic conditions in which they work.
\end{abstract}

Key words: psychological contract, breach, job satisfaction, employees.

JEL Classification: J28, J29, J41

\section{INTRODUCTION}

Relationship between an employer and an employee is primarily defined by the contract which both parties have to sign up before the employment agreement starts. By signing it, both parties confirm that they agree with the contract terms, i.e. with the obligations and rights that stem from this contract. However, both parties included in this relationship could also form additional expectations regarding their future exchange. These expectations are implicit and, hence, do not have to be signed in any document. The employers`additional expectations regarding the mutual exchange usually refer to

Received March 17, 2018 / Revised April 17, 2018 / Accepted April 20, 2018

Corresponding author: Sandra Milanović

* PhD student at University of Niš, Faculty of Economics

Faculty of Economics Niš, Trg kralja Aleksandra 11, 18000 Niš, Serbia

E-mail: sandramilanovic89@yahoo.com 
that the employees should be loyal to the company, that they will work overtime when it is necessary, etc. When it comes to the additional expectations of the employees, they usually refer to the future promotions, job security, earnings, etc. These implicit expectations are an integral part of the so called psychological contract (Argyris, 1960; Levinson et al., 1962; Rousseau, 1989; Robinson \& Rousseau, 1994; Morrison \& Robinson, 1997).

The basic characteristic of this contract is that it has no written form. From this fact steams another one: it has no legal strength. Therefore, in the case of breaching there will not be any legal consequences. But nevertheless, many negative effects could also appear. In many studies it was found that psychological contract breach caused a lower trust of the employees (Robinson \& Rousseau, 1994; Morrison \& Robinson, 1997; Raja et al., 2004), lower commitment (Rousseau, 1990; Robinson et al. 1994; Anderson \& Schalk, 1998; Robinson \& Morrison, 1995; Cassar \& Briner, 2011), reduced motivation (Pines, 2002; Parzefall \& Hakanen, 2010), decreased performance (Turnley et al., 2003; Zhao et al., 2007), higher absenteeism (Hackett, 1989; Griffeth et al., 2000) and higher turnover intentions (Robinson \& Rousseau, 1994; Zhao et al., 2007; Suazo, 2009; Hess \& Jepsen, 2009) etc.

One of the negative consequences resulting from the psychological contract breach is decrease of employees' job satisfaction as well. Job satisfaction is a phenomenon that reflects how employees feel towards their job in general or some aspects of the job (work tasks, salary, promotion and other incentives, working conditions, relationship with coworkers and job security) (Spector, 1997). Many studies, that have been conducted so far, have confirmed that when employees experience the psychological contract breach, their job satisfaction decreases (Robinson \& Rousseau, 1994; Knights \& Kennedy, 2005; Zhao et al., 2007; Suazo, 2009). However, regarding these studies one important fact arises: these kinds of researches were mostly done in developed countries and are quite rare in developing countries, such as Serbia. On the other hand, the context in which employees work in developing countries is quite different comparing to the developed countries. In developing countries unemployment rate is usually much higher than in developed countries, while the living standard is at the lower level ${ }^{2}$. As a consequence of these unfavorable economic conditions, many highly educated people in developing countries accept the jobs that are under their capabilities. Yet, these jobs provide them financial resources for everyday living. Having in mind all these facts, the question that arises here is whether psychological contract breach in developing countries influences job satisfaction in the same way as it does in developed countries (negatively), or since in developing countries it is hard to get any kind of job, psychological contract breach does not negatively influence job satisfaction.

In order to find out the answer to these questions, the authors of the paper carried out an empirical research. It was conducted by the case study method. The paper is structured as follows: In the first part of the paper, the literature reviews on psychological contract and job satisfaction is given. In the second part, the methodology of the research, the

\footnotetext{
2 According to the data of Statistical Office of the Republic of Serbia, the unemployment rate in Serbia for the last few years has been between $15 \%$ and $20 \%$, while in the USA, where most of the research has been done, it was around 4,3\% (United States Department of Labor, Bureau of Labor Statistics, 2017). When it comes to the average net salary, in Serbia in October 2017 it was around \$ 460 (Statistical Office of the Republic of Serbia, 2017), while median weekly earnings of full-time wage and salary workers in USA in the third quarter of 2017 were \$ 859 (United States Department of Labor, 2017).
} 
research results and their discussion are presented. The final part of the paper refers to the practical implication of the paper and concluding remarks.

\section{LITERATURE REVIEW}

\subsection{Psychological contract}

The term "psychological work contract" was used for the first time by Argyris (1960). He perceived the psychological contract as an implicit agreement between employees and their supervisors regarding the exchange that would happen between them. Levinson $e t$ al. (1962) also highlighted that psychological contract refers to the mutual expectations between an employee and the employer, but suggested that each party may not even be aware of their own expectations since they could have subconscious background (Levinson et al., 1962). Schein (1978) also made a significant contribution to the conceptualization of the psychological contract. He stated that psychological contract is "a set of unwritten reciprocal expectations between an individual employee and the organization" (Schein, 1978, p. 48) stressing that there is a match in expectations between employee and organization. This congruence, on the other hand, is crucial to attaining many positive outcomes such as job satisfaction, commitment and performance (CoyleShapiro et al., 2008).

Probably the most significant contribution to the development of the theory of the psychological contract in recent period was given by Denise Rousseau. She was the first one who defined the psychological contract from an individual's perspective, stating that it represents "an individual's belief regarding the terms and conditions of a reciprocal exchange agreement between that focal person and another party (usually between an employer and an employee)" (Rousseau, 1989, p.123). Later, she simplified her first definition, stating that psychological contract in "an individual's beliefs regarding reciprocal obligations" (Rousseau, 1990, p. 390) and suggesting that the parties in the relationship do not necessarily need to agree on the content of the contract.

The general opinion in the literature is that there are two basic types of psychological contract. These are the "old" psychological contract and the "new" psychological contract. The basic feature of the "old" psychological contract is employees' beliefs that if they work hard, adequately fulfill their obligations to the employer and contribute to the achievement of company's goals, they can count on job security (Dunahee \& Wangler, 1974; Rousseau 1989; Sims, 1994; Makin et al. 1996; Singh, 1998). However, after the 80s of the $20^{\text {th }}$ century, when many companies went through mergers, acquisitions and downsizing processes (and consequently many employees were laid off), employees started to form the "new" psychological contract. Its fundamental characteristic is that employees can not count on job security anymore, but the best that they can get from the employers are fair salary and opportunities for personal growth (Sims, 1994; Robinson et al.,1994; Kissler, 1994; Sparrow, 1996; Hiltrop, 1996; Schalk \& Roe 2007).

Psychological contracts could also be distinguished upon whether financial or relational elements dominate in their content. Accordingly, there are two types of psychological contracts: transactional and relational (MacNeil, 1980; Rousseau, 1990; Robinson et al., 1994). Since any psychological contract is not purely transactional or relational, recently two additional forms have been identified. These are balanced psychological contract (it has the 
same characteristics as relational psychological contract, but also contains financial elements) and transitional psychological contract (it forms in the period of a crisis or when a company is undergoing some radical organizational changes) (Rousseau, 2004).

The most important issue from the employees' perspective is whether their expectations are fulfilled. If that is not the case, their psychological contract is, actually, breached. Some authors insist on a distinction between two terms - violation and breach of psychological contract. According to Morrison and Robinson (1997) "perceived breach refers to the cognition that one's organization has failed to meet one or more obligations within one's psychological contract in a manner commensurate with one's contributions" (Morrison \& Robinson, 1997, p. 230). Therefore, perceived breach represents a cognitive assessment of contract fulfillment, based on an employee's perception. On the other hand, term violation refers to the "emotional and affective state that may, under certain conditions, follow from the belief that one's organization has failed to adequately maintain the psychological contract" (Morrison \& Robinson, 1997, p. 230). Thus, violation is considered as an emotional experience.

Perceived psychological contract breach may occur for many reasons, but two main causes are identified: reneging and incongruence (Morrison \& Robinson, 1997). Reneging refers to the situation when organizational agents knowingly fail to meet their obligations and promises towards an employee. It occurs either because the organization is unable to fulfill given promises or because it is unwilling to do so. Incongruence, on the other hand, is a situation when an employee and agents of the organization have different understanding about the mutual obligations and promises. These different perceptions usually appear due to the complexity and ambiguity of reciprocal obligations and expectations, bad communication between employees and organizational agents and disparity in cognitive schemata they possess.

\subsection{Job satisfaction}

Job satisfaction as a phenomenon could be seen as a global feeling about a job or as a constellation of the attitudes about various aspects of a job (Spector, 1997). It could also be defined as a result of a cognitive, affective and evaluative reaction of an individual on various dimensions of job (Judge at al., 2001). However, the most cited definition of job satisfaction in literature is probably Locke's definition who states that job satisfaction is "a pleasurable or positive emotional state resulting from the appraisal of one's job or job experiences" (Locke, 1976, p. 1304).

Very useful opinions that enable understanding of this concept are also the opinions of McShane (2004) and Fako et al. (2009). According to McShane (2004), job satisfaction represents the level of divergence between what a worker expects to receive and what he/she actually experiences in the workplace (McShane, 2004). Furthermore, Fako et al. (2009) state that if one expects little and gets little, he/she would be satisfied as much as one who expects a lot and gets a lot. On the other hand, if one expects a lot and gets little, he/she would be dissatisfied (Fako et al., 2009).

Job satisfaction is a very complex phenomenon which could be influenced by various factors. Based on their nature, there are three basic models which explain the causality of job satisfaction. These models are: situational model, dispositional model and interactional model (Judge \& Klinger, 2008). The situational model of job satisfaction is based on the premise that 
job satisfaction stems from the job characteristics or other aspects of the work environment. According to this model, job satisfaction could be influenced by the salary, job tasks, possibilities for promotion, relationship with co-workers etc. (Spector, 1997; Giri \& Kumar, 2010; Hauff et al., 2015). On the other hand, the dispositional model is based on the premise that certain relatively stable personal characteristics influence job satisfaction regardless of the job characteristics and situation. Judge and his colleagues (1998), for example, proposed that there are four personal characteristics that determine one's disposition towards job satisfaction. These are: self-esteem, general self-efficacy, locus of control and neuroticism (Judge et al., 1998). These authors state that higher levels of self-esteem and general self-efficacy lead to higher job satisfaction. In addition, they also found that job satisfaction is associated with internal locus of control and lower level of neuroticism (Judge et al., 1998). Finally, the interactional model of job satisfaction is based on the premise that the fit between a person and the environment influences job satisfaction (Chatman, 1989).

One of the situational factors which have a proven negative effect on employees job satisfaction is breaching of their psychological contract. This has been confirmed in numerous studies that have been conducted in developed countries so far (Robinson \& Rousseau, 1994; Knights \& Kennedy, 2005; Zhao et al., 2007; Suazo, 2009). However, the context in which employees work in developed countries is quite different comparing to the context of work of employees in developing countries. In developing countries, the employees are faced with high rate of unemployment, low living standard etc., so the question that arises here is whether psychological contract breach in such context influences job satisfaction of employees in the same way as it does in developed countries - negatively. In order to find out the answer to this question the hypothesis that will be tested in our research are as follows:

H1: There is a negative relationship between psychological contract breach and job satisfaction.

H2: Psychological contract breach influences negatively job satisfaction of the employees in the context of high unemployment rate and low living standard.

\section{Methodology of ReSEARCH}

Method of the research. For the purpose of testing the above hypothesis, an empirical research has been conducted. Empirical research has been carried out by the case study method. This method was chosen since such empirical research has not been conducted on the territory of the Republic of Serbia so far, and since this research is the first phase of a more comprehensive one.

Content of the research. The research has been conducted in the company Aura which was founded in 1996 in Nis as a company for the production and sale of cosmetics. Nis is one of the largest cities in Serbia where the unemployment rate is very high, especially among the younger people. A few decades ago, this city was the center of electronic, mechanical and tobacco industry, with some of the most successful companies of that time. However, since the $90 \mathrm{~s}$, due to the transition process, the country went through many economic and political challenges. The industry collapsed and around 40.000 people in Nis have lost their jobs. The city was faced with catastrophic economic situation 
and has not been able to recover ever since. Although the number of unemployed has slightly decreased in the last couple of years, mainly because of the foreign investors and their companies, it is still very high.

Research variables and instruments. Regarding the psychological contract breach, we used the questionnaire created by Robinson \& Morrison (2000). For gathering the data about job satisfaction, we used the questionnaire created by Eisenberger et al. (1997). Each item in questionnaires was assessed using five-point Likert scale, ranging from 1 strongly disagree, to 5 - strongly agree. An answer of 4 or more points expresses high level of agreement, answer of 3 points indicates neutral opinion, while low level of agreement is expressed by an answer below 3 points. Since there were reverse questions in the part of psychological contract breach questionnaire, a reversal of initial coding was applied during the analysis.

Data collection techniques and instruments. The number of questionnaires that were distributed was 100. The questionnaires in paper form were distributed during May of 2017. The response rate was $60 \%$. There was no missing data and all returned questionnaires were used and analyzed.

Sample characteristics. The demographic characteristics of the respondents are presented in the Table 1.

Table 1 Respondent Characteristics

\begin{tabular}{lrr}
\hline Variable & Frequency & Percent \\
\hline Gender & 60 & 100 \\
Male & 16 & 26.7 \\
Female & 44 & 73.3 \\
Age & 60 & 100 \\
$<25$ & 2 & 3.3 \\
$26-40$ & 28 & 46.7 \\
$41-55$ & 26 & 43.3 \\
$>55$ & 4 & 6.7 \\
Education & 60 & 100 \\
III level & 8 & 13.3 \\
IV level & 32 & 53.3 \\
VI level & 2 & 3.3 \\
VII level & 16 & 26.7 \\
VIII level & 2 & 3.3 \\
Work experience in current job & 60 & 100 \\
<1 year & 2 & 3.3 \\
1-5 years & 20 & 33.3 \\
6-10 years & 2 & 3.3 \\
11-20 years & 34 & 56.7 \\
21-30 years & Source: Authors' calculations
\end{tabular}

Analyses and procedures. The collected data were analyzed using the program IBM SPSS, version 23. Regarding the purpose and objectives of the research we used ANOVA test and linear regression. 


\section{THE RESULTS AND DiSCUSSION}

In order to evaluate internal consistency of the instruments, Cronbach's alpha coefficient was calculated. The Cronbach's alpha coefficient of job satisfaction was 0.75 while for psychological contract breach it was 0.83 . In both cases the values of calculated coefficients indicated that the instruments have sufficient internal reliability.

The questionnaire created by Robinson \& Morrison (2000) with five items was used to measure the level of psychological contract breach of the participants. The following table presents the minimum, the maximum and the mean values, as well as the standard deviation of each item in the questionnaire.

Table 2 Descriptive statistics of the items measuring psychological contract breach

\begin{tabular}{lccccc}
\hline Item & $\mathrm{N}$ & Minimum & Maximum & Mean & $\mathrm{SD}$ \\
\hline $\begin{array}{l}\text { 1. Almost all of the promises made by my employer } \\
\text { during recruitment have been kept so far. }\end{array}$ & 60 & 1.00 & 4.00 & 1.80 & .92 \\
$\begin{array}{l}\text { 2. I feel that my employer has come through in } \\
\text { fulfilling the promises made to me when I was }\end{array}$ & 60 & 1.00 & 4.00 & 1.77 & .81 \\
$\quad$ hired. & & & & & \\
$\begin{array}{l}\text { 3. So far my employer has done an excellent job of } \\
\text { fulfilling their promises to me. }\end{array}$ & 60 & 1.00 & 5.00 & 1.87 & 1.00 \\
$\begin{array}{l}\text { 4. I have not received everything promised to me in } \\
\text { exchange for my contributions. }\end{array}$ & 60 & 1.00 & 4.00 & 2.23 & 1.06 \\
$\begin{array}{l}\text { 5. My employer has broken many of their promises to } \\
\text { me even though I have upheld my side of the deal. }\end{array}$ & 60 & 1.00 & 3.00 & 1.83 & .69 \\
\hline
\end{tabular}

Source: Authors' calculations

Table 2 presents original items that were set in questionnaire spread to the case study participants. Since the main aim of the questionnaire was to measure the level of psychological contract breach, the first three questions are reformulated in order to achieve negative formulation of all items. So, when reverse coding was done, answer of 5 points became 1 point on 5-point Likert scale used in this research. Right side of table 2 shows descriptive statistics for re-coded answers to first three items and for original answers to statements 4 and 5. It is notable in four of five questions that total breach of psychological contract does not exists. Although, there is an answer of 5 points to question 3 , the mean of this question is around same level as mean of other questions. The mean of all five items is lower then 3 and with all negatively formulated statements that means the employees believe that the employer fulfilled their expectations.

The following table presents descriptive statistics of the items defined by Eisenberger et al. (1997) for measuring the job satisfaction of employees.

Table 3 shows that in the company Aura there are employees who are totally dissatisfied with their job (the items 2, 3, and 4 are assessed with 1 point). However, there are also employees who are very satisfied with their job (all the items in the questionnaire are assessed with 5 points by certain employees). The presented data show that the first item has the least mean value - 3.73 (if a good friend of his/her said that he/she is interested in working in a job like his/hers, he/she would strongly recommend it). The 
mean values of the other answers are 4 points, or higher, indicating the high level of job satisfaction.

Table 3 Descriptive statistics of the items measuring job satisfaction

\begin{tabular}{|c|c|c|c|c|c|}
\hline Item & $\mathrm{N}$ & Minimum & Maximum & Mean & SD \\
\hline $\begin{array}{l}\text { 1. If a good friend of mine told me that he/she was } \\
\text { interested in working in a job like mine I would } \\
\text { strongly recommend it. }\end{array}$ & 60 & 2.00 & 5.00 & 3.73 & .82 \\
\hline 2. All in all, I am very satisfied with my current job. & 60 & 1.00 & 5.00 & 4.27 & .90 \\
\hline $\begin{array}{l}\text { 3. In general, my job measures up to the sort of job I } \\
\text { wanted when I took it. }\end{array}$ & 60 & 1.00 & 5.00 & 4.00 & 1.07 \\
\hline $\begin{array}{l}\text { 4. Knowing what I know now, if I had to decide all } \\
\text { over again whether to take my job, I would. }\end{array}$ & 60 & 1.00 & 5.00 & 4.33 & .88 \\
\hline
\end{tabular}

Following table represents the minimum, maximum and the mean value of psychological contract breach and job satisfaction and their standard deviations.

Table 4 Descriptive statistics of studied variables

\begin{tabular}{lccccc}
\hline Variable & $\mathrm{N}$ & Minimum & Maximum & Mean & Std. Deviation \\
\hline Psychological contract breach & 60 & 1.00 & 3.80 & 1.90 & .70 \\
Job satisfaction & 60 & 1.50 & 5.00 & 4.08 & .71 \\
\hline
\end{tabular}

Source: Authors' calculations

Table 4 shows that the mean value of psychological contract breach is 1.90 points which indicates relatively high level of perception that the employer fulfilled the expectations employees had. On the other hand, the mean value of job satisfaction is 4.08 points which represents relatively high level of job satisfaction. Standard deviations for both variables are close to 1 , which is at an acceptable level.

In order to test the hypothesis H1, we calculated the correlation between psychological contract breach and job satisfaction.

Table 5 Correlation between psychological contract breach and job satisfaction

\begin{tabular}{llcc}
\hline & & $\begin{array}{c}\text { Psychological } \\
\text { contract breach }\end{array}$ & Job satisfaction \\
\hline Psychological & Pearson Correlation & 1 & $-.479^{* *}$ \\
contract breach & Sig. (2-tailed) & 60 & .007 \\
& $\mathrm{~N}$ & $-.479^{* *}$ & 60 \\
Job satisfaction & .007 & 1 \\
& Pearson Correlation & 60 & 60 \\
& Sig. (2-tailed) & $\mathrm{N}$ & \\
& **. Correlation is significant at the 0.01 level (2-tailed). \\
& Source: Authors' calculations
\end{tabular}


Table 5 shows that the Pearson correlation coefficient is $-.479, \mathrm{p}<.01$ indicating that there is a negative correlation between psychological contract breach and job satisfaction of the employees.

Based on these results, it can be concluded that the research hypothesis H1, which states that there is a negative relationship between psychological contract breaches and job satisfaction, is confirmed. That means that as the level of psychological contract breach increases, the level of job satisfaction decreases.

For the purposes of this study, Pearson correlation coefficient values of \pm .10 represent a small effect, \pm .30 is a medium effect and \pm .50 is a large effect (Cohen, 1992). The results of study show that psychological contract breach is significantly and negatively related to job satisfaction $(\mathrm{p}<.01$, medium practical effect).

In order to investigate if there is the effect of psychological breach on job satisfaction, the linear regression coefficient was calculated (Table 6).

Table 6 Regression analysis of studied variables

\begin{tabular}{lrrrr}
\multicolumn{5}{c}{ Model Summary } \\
\hline Model & $\mathrm{R}$ & R Square & $\begin{array}{r}\text { Adjusted } \\
\text { R Square }\end{array}$ & $\begin{array}{l}\text { Std. Error of } \\
\text { the Estimate }\end{array}$ \\
\hline 1 & $.479^{\mathrm{a}}$ & .230 & .216 & .61884 \\
\hline
\end{tabular}

a. Predictors: (Constant), Psychological contract breach

ANOVA $^{\mathrm{a}}$

\begin{tabular}{llccccc}
\hline Model & & Sum of Squares & df & Mean Square & F & Sig. \\
\hline 1 & Regression & 6.622 & 1 & 6.622 & 17.291 & $.000^{\mathrm{b}}$ \\
& Residual & 22.212 & 58 & .383 & & \\
Total & 28.833 & 59 & & \\
\hline \multicolumn{5}{c}{ a. Dependent Variable: Job satisfaction } \\
& b. Predictors: (Constant), Psychological contract breach &
\end{tabular}

Coefficients

\begin{tabular}{|c|c|c|c|c|c|c|c|}
\hline \multirow[b]{2}{*}{ Model } & \multicolumn{2}{|c|}{$\begin{array}{c}\text { Unstandardized } \\
\text { Coefficients }\end{array}$} & \multirow{2}{*}{$\begin{array}{c}\begin{array}{c}\text { Standardized } \\
\text { Coefficients }\end{array} \\
\text { Beta }\end{array}$} & \multirow[b]{2}{*}{$\mathrm{t}$} & \multirow[b]{2}{*}{ Sig. } & \multicolumn{2}{|c|}{$\begin{array}{l}95.0 \% \text { Confidence } \\
\text { Interval for B }\end{array}$} \\
\hline & B & $\begin{array}{l}\text { Std. } \\
\text { Error }\end{array}$ & & & & $\begin{array}{l}\text { Lower } \\
\text { Bound }\end{array}$ & $\begin{array}{l}\text { Upper } \\
\text { Bound }\end{array}$ \\
\hline 1 (Constant) & 4.995 & .233 & & 21.406 & .000 & 4.528 & 5.462 \\
\hline $\begin{array}{l}\text { Psychological } \\
\text { contract } \\
\text { breach }\end{array}$ & -.480 & .115 & -.479 & -4.158 & .000 & -.711 & -.249 \\
\hline
\end{tabular}

a. Dependent Variable: Job satisfaction

Linear regression analysis in Table 6 shows that $\mathrm{R}$ value $=.479$ represents the correlation between psychological contract breach and job satisfaction. $\mathrm{R}$ Square $=.230$ indicates that $23.0 \%$ change in job satisfaction is due to psychological contract breach. $F=17.291$, is significant at the 0.000 level $(\mathrm{p}<.05)$, shows that there is a model fit between psychological contract breach and job satisfaction. Regression coefficient (B) of psychological contract 
breach of -.480 shows that 1 unit change in psychological contract breach will bring -.480 unit changes in job satisfaction.

Based on these results, it can be concluded that hypothesis $\mathrm{H} 2$ is confirmed, i.e. psychological contract breach negatively influences job satisfaction of the employees in the context of high unemployment rate and low living standard.

Although the sample in our research was small, comparing to the samples in similar studies conducted in developed countries, the results that we obtained are to some extent similar to the results that many other authors have found in their studies. For example, Zhao et al. (2007) also found that psychological contract breach is strongly correlated with job satisfaction $(r=-.54)$ indicating that as the level of psychological contract breach increases, the level of job satisfaction decreases. Furthermore, the results of our study are similar to the results of the study conducted by Suazo (2009). In this study, it was found that psychological contract breach is relatively strongly related to job satisfaction $(\mathrm{r}=$ .40). Suazo (2009) also found that psychological contract breach affects significant amount of variance of job satisfaction. He found that psychological contract breach explains 20 percent of variance in job satisfaction. The results of the study that we conducted are also similar to the results of the study conducted by Xiaoqing and his colleagues (2015). They have found that psychological contract breach has negative effect on job satisfaction $(\mathrm{r}=-0.39)$. They have also found that 15.5 percent of change in job satisfaction is due to psychological contract breach.

The findings in our research, that are supported by the literature, suggest that the employees, even though working in the conditions of high unemployment and low living standard, if they perceive that their expectations are not met by the employer, they will be less satisfied with their job.

\section{CONCLUSION}

In this paper, we analyzed the relationship between the psychological contract breach and job satisfaction of the employees in the company Aura founded in Nis (Serbia). This study has been conducted by the case study method which is generally suitable for examination the phenomena which have not previously been the subject of a comprehensive research and when it is necessary to determine the possible directions in further research (Evers \& van Staa, 2010). These conditions were fulfilled in our research: the relationship between psychological breach and job satisfaction has not been examined on the territory of the Republic of Serbia and this research is the first phase of the more comprehensive one. Therefore, this method was the optimal solution for the research we conducted.

The result of the study showed that there is statistically significant negative relationship among these variables. The linear regression analysis showed that 23 percent of change in job satisfaction is due to the psychological contract breach. Furthermore, it was also found that psychological contract breach influences job satisfaction, so if psychological contract breach increases for 1 unit that will bring decrease in job satisfaction for 0.480 units. Since the results also showed that the employees in this company generally believe that the employer fulfilled their expectations (mean value of breaching the psychological contract is 1.90), managers of this company should continue to dedicate attention to the communication 
with employees in order to help them create realistic expectations. Furthermore, the management should keep all of its promises that are made to the employees.

Based on the implemented method of the empirical research, there are some limitations of this study. First, because of the small sample, generalizations for the sector of cosmetics production or the whole private and public sector in Serbia can not be made. Second, the data has been collected via questionnaire with limited number of the items (especially when it comes to the job satisfaction), so it was not possible to determine which job related characteristics produce the lowest level of job satisfaction. That information would be useful for creating effective human resource management practices. In order to overcome these limitations, our future research will be based on a bigger sample and the questionnaire regarding the job satisfaction with more items will be used.

\section{REFERENCES}

Argyris, C. (1960). Understanding Organizational Behavior. Homewood, IU.: Dorsey Press.

Anderson, N. \& Schalk, R. (1998). The psychological contract in retrospect and prospect. Journal of Organizational Behavior, 19, 637 - 647.

Azeem, S.M. (2010). Job satisfaction and organizational commitment among employees in the Sultanate of Oman. Psychology, 1 (4), 295-300.

Barnard, C. (1938). The Functions of the Executive. Cambridge, MA: Harvard University Press.

Carsten, J.M. \& Spector, P.W. (1987). Unemployment, job satisfaction, and employee turnover: A metaanalytic test of the Muchinsky model. Journal of Applied Psychology, 72 (3), 374-381.

Cassar, V. \& Briner, R. (2011). The Relationship between Psychological Contract Breach and Organizational Commitment: Exchange Imbalance as a Moderator of the Mediating Role of Violation. Journal of Vocational Behavior, 78, 283-289.

Chatman, J. (1989). Improving interactional organizational research: A model of person-organization fit. Academy of Management Review, 14, 333-349.

Cohen, J. (1992). Quantitative methods in psychology: A power primer. Psychological Bulletin, 112 (1), $153-159$.

Conwey, N. \& Briner, R. (2005). Understanding psychological contract at work: A critical evaluation of theory and research. Oxford University Press.

Coyle-Shapiro, Jacqueline A-M. \& Parzefall, M. (2008) Psychological contracts. In: Cooper, Cary L. and Barling, Julian, (eds.) The SAGE handbook of organizational behavior. SAGE Publications, London, UK, pp. 17-34.

Dunahee, M.H. \& Wangler, L.A. (1974). The Psychological Contract: A Conceptual Structure for Management/ Employee Relation. Personnel Journal, 7, 518-526.

Đorđević, B. (2007). The nature of the psychological employment contract. Economic themes, 45 (4), $131-142$.

Đorđević, B., Đukić-Ivanović, M. \& Lepojević, V. (2017). Relationship of ages and gender of the employees in organizations in the Republic of Serbia and their job satisfaction. Economic Themes, 55 (2), 263-280.

Evers, J.C. \& van Staa, A.L. (2010). Qualitative analysis in case study. In Albert J. Mills, Gabrielle Durepos \& Elden Wiebe (Eds.), Encyclopedia of case study research (pp.750-758). Thousand Oaks, CA: Sage.

Fako, T.T., Moeng, S.R.T. \& Foreheh, N. (2009). Gender Differences in Satisfaction with the Type of Work University Employees Do: Evidence from the University of Botswana. Journal of Service Science and Management, 2 (4), 404-417.

Giri, V.N. \& Kumar, B.P. (2010). Assessing the impact of organizational communication on job satisfaction and job performance. Psychological Studies, 55 (2), 137-143.

Griffeth, R.W., Hom, P.W. \& Gaertner, S. (2000). A meta-analysis of antecedents and correlates of employee turnover: Update, moderator tests, and research implications for the next millennium. Journal of Management, 26 (3), 463-488.

Gu Z. \& Chi, R.S.S. (2009). Drivers of job satisfaction as related to work performance in Macao casino hotels: An investigation based on employee survey. International Journal of Contemporary Hospitality Management, 21 (5), 561- 578.

Hackett, R.D. (1989). Work attitudes and employee absenteeism: A synthesis of the literature. Journal of Occupational Psychology, 62 (3), 235-248. 
Hauff, S., Richter F.N. \& Tressin, T. (2015). Situational job characteristics and job satisfaction: The moderating role of national culture. International Business Journal, 24, 710-723.

Hess, N. \& Jepsen, D.M. (2009). Career stage and generational differences in psychological contracts. Career Development International, 14, 261-283.

Hiltrop, J.M. (1996). Managing the changing psychological contract. Employee Relations, 18 (1), 36-50.

Judge, T.A., Locke, E.A., Durham, C.C. \& Kluger, A.N. (1998). Dispositional effects on job and life satisfaction: the role of core evaluations. Journal of Applied Psychology, 83 (1), 17-34.

Judge, T.A. Thoresen, C.J., Bono, J.E. \& Patton, G.K. (2001). The job satisfaction job performance relationship: A qualitative and quantitative review. Psychological Bulletin, 127, 376-407.

Judge, T.A. \& Klinger, R. (2008). Job satisfaction: Subjective well-being at work. In M. Eid, R. Larsen (Eds.), The Science of Subjective Well-Being (Ch. 19, pp. 393-413). Guilford Publications. New York.

Kissler, G.D. (1994). The new employment contract. Human Resource Management, 33, 335-352.

Knights, J.A. \& Kennedy, B.J. (2005). Psychological contract violation: Impact on job satisfaction and organizational commitment among Australian senior public servants. Applied H.R.M. Research, 10 (2), 57-72.

Kotter, J.P. (1973). The Psychological Contract, California Management Review, 15, 91-99.

Kuzey, C. (2012). Impact of Health Care Employees' Job Satisfaction On Organizational Performance Support Vector Machine Approach. European Journal of Economic and Political Studies, 5 (1), 65-89.

Latif, M.S., Ahmad, M., Qasim, M., Mushtaq, M., Ferdoos, A. \& Naeem, H. (2013). Impact of employee's job satisfaction on organizational performance. European Journal of Business and Management, 5 (5), 166-171.

Levinson, H., Price, R.C., Munden, J.K., Mandl J.H. \& Solley, M.C. (1962). Men, management and mental health, Harvard University Press.

Locke, E.A. (1976). The nature and causes of job satisfaction. In M. D. Dunnette (Ed.), Handbook of Industrial and Organizational Psychology (pp. 1297-1349). Chicago: Rand McNally College Publishing Company.

MacNeil, I.R. (1980). The new social contract: An inquiry into modern contractual relations, New Haven: Yale University Press.

Makin, P.J., Cooper, C.L. \& Cox, C.J. (1996). Organizations and the psychological contract: managing people at work. Leicester: The British Psychological Society.

March, J.G., Simon, H.A. (1958). Organizations. New York: Wiley.

McShane, S. (2004). Canadian Organizational Behavior (5th ed.). Toronto: McGraw-Hill Ryerson.

Menninger, K. (1958). Theory of psychoanalytic technique. Basic Books, Inc. New York.

Meyer, J. \& Allen, N. (1984). Testing the "side bet theory" of organizational commitment: some methodological considerations. Journal of Applied Psychology, 69, 372-378.

Morrison, W.E. \& Robinson, L.S. (1997). When employees feel betrayed: A model of how psychological contract violation develops. Academy of Management Review, 22, 226-256.

Oshagbemi, T. (2003). Personal correlates of job satisfaction: empirical evidence from UK universities. International Journal of Social Economics, 30 (12), 1210-1232.

Parzefall, M.R. \& Hakanen, J. (2010). Psychological contract and its motivational and health-enhancing properties. Journal of Managerial Psychology, 25 (1), 4-21.

Pines, A.M. (2002). The Changing Psychological Contract At Work And Employee Burnout. Journal of Health and Human Services Administration. 25, 11-32.

Raja, U., Johns, G. \& Ntalianis, F. (2004). The impact of personality on psychological contracts. Academy of Management Journal, 47, 350-367.

Reading, MA. Shore, L. \& Tetrick, L. (1994). The Psychological Contract as an Explanatory Framework in the Employment Relationship in C. Cooper, \& D. M. Rousseau (Eds), Trends in Organizational Behavior. New York: Wiley.

Robinson, S.L. \& Rousseau, D.M. (1994). Violating the psychological contract: Not the exception but the norm. Journal of Organizational Behavior, 15, 245-259.

Robinson, S.L. (1996). Trust and Breach of the Psychological Contract. Administrative Science Quarterly, 41 (4), 574-599.

Robinson, S.L., Kraatz, M. \& Rousseau, D.M. (1994). Changing obligations and the psychological contract: A longitudinal study. Academy of Management Journal, 37, 137-152.

Robinson, S.L. \& Morrison, W.E. (1995). Psychological contracts and OCB: The effect of unfulfilled obligations on civic virtue behaviour. Journal of Organizational Behavior, 16, 289-298.

Rousseau, D.M. (1989). Psychological and implied contracts in organizations. Employer Responsibilities and Rights Journal, 2, 121-139.

Rousseau, D.M. (1990). New hire perspectives of their own and their employer's obligations: A study of psychological contracts. Journal of Organizational Behavior, 11, 389-400. 
Rousseau, D.M. (1995). Psychological contracts in organizations: Understanding written and unwritten agreements. Newbury Park, CA: Sage.

Rousseau, D.M. (2004). Psychological Contracts in the Workplace: Understanding the Ties That Motivate. Academy of Management Executive, 18 (1), 120-127.

Schalk, R. \& Roe, R. (2007). Towards a Dynamic Model of the Psychological Contract. Journal for the Theory of Social Behavior, 37 (2), 167-182.

Schein, E.H. (1978). Career Dynamics: Matching Individuals and Organizational Needs. Addison-Wesley.

Sims, R.R. (1994). Human resource management's role in clarifying the new psychological contract. Human Resource Management, 33 (3), 373-382.

Singh, R. (1998). Redefining psychological contracts with the U.S. workforce: A critical task for strategic human resource management planners in the 1990s. Human Resource Management, 37 (1), 61-69.

Sparrow, P.R. (1996). Transitions in the psychological contract: Some evidence from the banking sector. Human Resource Management Journal, 6 (4), 75-92.

Spector, P.E. (1997). Job Satisfaction: Application, Assessment, Causes, and Consequences. United Kingdom: Sage Publications Ltd.

Suazo, M. (2009). The mediating role of psychological contract violation on the relations between psychological contract breach and work-related attitudes and behaviors. Journal of Managerial Psychology, 24 (2), 136-160.

Turnley, W.H., Bolino, M.C., Lester, S.W. \& Bloodgood, J.M. (2003). The impact of psychological contract fulfillment on the performance of in-role and organizational citizenship behaviors. Journal of Management, 29 (2), 187- 206

Xiaoqing X., Hanmin L. \& Huang D. (2015). Psychological Contract Breach and Turnover Intention. The Intermediary Role of Job Satisfaction. Open Journal of Business and Management, 3, 371-379.

Zhao, H., Wayne J.S., Glibkowski, C.B. \& Bravo, J. (2007). The impact of psychological contract breach on work-related outcomes: A meta-analysis. Personnel Psychology, 60, 647-680.

\section{UTICAJ KRŠENJA PSIHOLOŠKOG UGOVORA NA ZADOVOLJSTVO POSLOM}

Psihološki ugovor predstavlja implicitne pretpostavke zaposlenog (ili poslodavca) u pogledu sadržaja njihove međusobne razmene, pored onih koje su specificirane u formalnom ugovoru o radu. U slučaju njegovog kršenja, može doći do mnogih negativnih posledica. Jedna od njih je niži nivo zadovoljstva poslom. U studiji koja je sprovedena pokušali smo da nađemo odgovor da li je kršenje psihološkog ugovora u nepovoljnim ekonomskim uslovima negativno uticalo na zadovoljstvo poslom, kao što je utvrđeno u većini studija sprovedenih u razvijenim zemljama. Metod istraživanja koji smo koristili bio je metod studije slučaja. Da bismo testirali hipotezu, koristili smo anova test i linearnu regresiju. Rezultati studije su pokazali da kršenje psihološkog ugovora negativno utiče na zadovoljstvo poslom zaposlenog uprkos nepovoljnim ekonomskim uslovima u kojima rade.

Ključne reči: psihološki ugovor, kršenje, zadovoljstvo poslom, zaposleni 